\title{
Consuming common dreams with care!
}

Keywords: Whales, salmon, herring, clams, mussels, human development report, environmental science

\section{Introduction}

On March 24, 1989 Supertanker Exxon Valdez ran aground on Bligh Reef in Prince William Sound, Alaska. 11 million gallons of crude oil spilled across 1,500miles of shoreline. 500,000 birds of around 90 different species, including 150 bald eagles, 4,500sea otters, 14 killer whales, salmon, herring, clams, mussels, seaweed was killed. The incident left immeasurable toll on tourism and fishing industry. Minamata disease was first discovered in Minamata city in Kumamoto prefecture, Japan, in 1956. It was caused by the release of methylmercury in the industrial wastewater from the Chisso Corporation's chemical factory, which continued from 1932 to 1968 . Hundreds of people suffered neurodegenerative diseases and premature death.

From 1994 to early 2008, the region of Campania in south-west Italy existed under a formal State of Emergency, declared due to the saturation of regional waste treatment facilities. There is growing evidence, including a World Health Organization (WHO) study of the region, that the accumulation of waste, illegal and legal, urban and industrial, has contaminated soil, water, and the air with a range of toxic pollutants including dioxins. A high correlation between incidences of cancer, respiratory illnesses, and genetic malformations and the presence of industrial and toxic waste landfills was also found. The Government has been unable to resolve this crisis, adopting measures that have only increased public unrest, exacerbating the conflict.

According to a World Health Organization study, out of India's 3,119towns and cities, just 209 have partial sewage treatment facilities, and only 8 have full wastewater treatment facilities. Over 100 Indian cities dump untreated sewage directly into the Ganges River. Investment is needed to bridge the gap between 29, 000million litres per day of sewage India generates, and a treatment capacity of mere 6000 million litres per day. The case studies above though are strikingly different but they have a common thread of how our environment is facing a grim crisis and sustainability a question. Uneven consumption rates of ever increasing population across the world are taking a lethal toll on our natural resources and environment; in general.

Poverty and environmental degradation are closely interrelated. Indian Prime Minister Smt. Indira Gandhi during United Nations Conference on Environment and Development (UNCED) in Stockholm (1972) once said, 'Poverty is the greatest polluter'. While poverty results in certain kinds of environmental stress, the major cause of the continued deterioration of the global environment is the unsustainable pattern of consumption and production, particularly in industrialized countries, which is a matter of grave concern, aggravating poverty and imbalances.

The Human Development Report (1998) highlights how today's consumption is undermining the environmental resource base. It is exacerbating inequalities. And the dynamics of the consumptionpoverty-inequality-environment nexus are accelerating. If the trends continue without change - not redistributing from high-income to low-income consumers, not shifting from polluting to cleaner goods
Volume I Issue 6 - 2017

\author{
Joystu Dutta \\ Department of Environmental Science, Sarguja University, India
}

Correspondence: Joystu Dutta, Assistant Professor, Department of Environmental Science, Sarguja University, Ambikapur - 49700I, Chhattisgarh, India, Email joystu.dutta@gmail.com

Received: December 05, 2017 | Published: December 29. 2017

and production technologies, not promoting goods that empower poor producers, not shifting priority from consumption for conspicuous display to meeting basic needs-today's problems of consumption and human development will worsen. Take for example the United States. With around 5 percent of the world's population, the US consumes about $40 \%$ of the world's resources and emits around $21 \%$ of the world's carbon dioxide, a greenhouse-causing gas. The United States, however, is not over-populated, but the consumption-based life style does have its effects.

That is not to say that there are no problems in developing countries! In India for example, Delhi is a good example of a growing city. However, with this development come serious growing pains, such as pollution and unsustainable resource management. We are all aware of the smog that enveloped Delhi few weeks ago resulting in road-accidents, breathing problems and lung ailments. Normal life came to a halt as a result of the severe pollution. United Arab Emirates, Kuwait and some other nations, show higher per capita energy consumption (UAE being higher than the U.S.). However, the same World Bank report also points out that these are net exporters of energy - that is, they produce oil that is exported - and hence consumes far less domestically than the US and other wealthy nations that typically largely purchase that oil. The United States consumes more than anyone else does, followed by Germany and Japan and the Russian Federation. For example, one American consumes as much energy as 41 Bangladeshis as empirical studies show, even though the American population is just over twice as large as that of Bangladesh.

There, quoting from the UN population data on where most growth is in population, they say that, "Six countries account for half of this annual growth: India for 21 per cent; China for 12 per cent; Pakistan for 5per cent; Nigeria for 4 per cent; Bangladesh for 4 per cent, and Indonesia for 3 per cent". The report also mentions, "The United States, Japan, and other high-income countries, with 15percent of the world's population, consume half of the world's commercial energy". Mahatma Gandhi once quoted, "Earth provides enough to satisfy every man's need but not every man's greed". The increasing rates of natural hazards, global warming, fluctuations in temperature and erratic monsoon pattern, food insecurity, water wars pose a unique question before the mankind. It is time for us to be more responsible, more sustainable to ensure a better tomorrow for our progenies. The 
entire blue planet is linked by a common thread where we share the similar natural resources and equations of life and sustenance. An acre of forest loss in Amazon can pose a threat to the existence of Kiribati islands in Pacific. Loss of a flagship species from Himalayas can have a negative effect on the species distribution across the world, in general. An oil spill incident in Mediterranean sea do have a long term effect on the migratory bird populations across the world, an incident of Tsunami in Japan can rock the small island countries spread across our planet. Melting of polar ice can wreck havoc in coastal towns of Bangladesh and Sri Lanka.

Thus we have a common but differentiated responsibility, as earmarked in the Kyoto Protocol. We must be logical and sensible enough in allowing environment and development go hand in hand, not one at the cost of the other. This is the time to act locally and think globally instead of hobnobbing in chaotic climatic debates and conferences yielding no promising consequences. Only then can we give wings to the ignited dreams of seven billion dreamers across the world. I will end up with the immortal quote of Mahatma Gandhi; "The earth, the air, the land and the water are not an inheritance from our fore fathers but on loan from our children. So we have to handover to them at least as it was handed over to us".
Celebrated environmental evangelist and noble laureate Madam Wangari Maathai once quoted- "Today we are faced with a challenge that calls for a shift in our thinking, so that humanity stops threatening its life-support system. We are called to assist the Earth to heal her wounds and in the process heal our own - indeed to embrace the whole of creation in all its diversity, beauty and wonder. Recognizing that sustainable development, democracy and peace are indivisible is an idea whose time has come"

A consensus and unified approach towards sustainability is the only solution to the overarching problem that envelops humanity. We require more and more friends of nature as Waangari Maathai, Rabindranath Tagore, Sunderlal Bahuguna, Eugene P. Odum or Rachel Carson who took out leaves from the pages of their celebrated life to work and act for a meaningful and better tomorrow.

\section{Acknowledgements}

None.

\section{Conflict of interest}

Author declares there is no conflict in interest in publishing the article. 